\title{
GROWTH AND YIELD OF HIGH PROTEIN CORN (ZEA MAYS L) AS INFLUENCED BY PLANT SPACING AND NPK LEVELS
}

\author{
ARNOLD V. DAMASO \\ College of Agriculture, Nueva Ecija University of Science and Technology-Gabaldon Campus, Gabaldon, Nueva Ecija 3131, \\ Philippines
}

\begin{abstract}
In crop production, major production variables that a producer can manipulate to influence the production of a given crop are agronomic practices, fertilizer levels and plant spacing require special attention in the changing climatic condition. The following treatments were used: plant spacing $(P 170 \mathrm{~cm} \times 20 \mathrm{~cm} ; P 260 \mathrm{~cm} \times 25 \mathrm{~cm} ; P 360 \mathrm{~cm} \times 20 \mathrm{~cm}) w e r e$ used as the main treatments and the NPK levels (F1 100-40-20 kg ha-1; F2 130-40-20 kg ha-1; F3 160-40-20 kg ha-1; F4 100-40-60 kg ha-1; F5 130-40-60 kg ha-1; F6 160-40-60 kg ha-1) were utilized as sub-treatments. This study was conducted at Integrated Sustainable Agri-Techno Demo Farm at Pangasinan State University. Standard conventional procedure in corn production was followed throughout the duration of the study. It can be concluded that there was significant interaction (plant spacing and NPK levels) in plant height, ear height, ear length and ear diameter, ear harvest per plot, kernel row per ear, number of kernels per ear, weight of 1000 kernels on growth and yield of high protein corn. Based on the results of the study, plant spacing of $60 \mathrm{~cm} \times 25 \mathrm{~cm}$ and $60 \mathrm{~cm} \times 20 \mathrm{~cm}$ and NPK levels at the rate of 130-40-60 $\mathrm{kg} \mathrm{NP2O5K2O} \mathrm{ha-1} \mathrm{and} 160$ - 40 - $60 \mathrm{~kg}$ NP2O5K2O ha-lincreased the growth and yield parameters of high protein corn. Application of fertilizer combinations during the crop production was effective which contributed to the increased yield.

KEYWORDS: Crop Production, Plant Spacing, Nutrient Management, NPK Levels, High Protein Corn, Climate Change, Yield
\end{abstract}

Received: May 10, 2020; Accepted: Jun 01, 2020; Published: Jun 30, 2020; Paper Id.: IJMPERDJUN2020189

\section{INTRODUCTION}

The Philippines has been affected by globalization. Economically, it has to compete with other developed nations in the efficient production and marketing of agricultural products. To meet this demand, innovative production methods applicable to our country economic conditions must be employed. Thus, the role of researchers is very important in attaining innovations in agricultural production to meet the demands of a fickle market (Damaso, 2013).

Corn (Zea Mays L.) known as "Queen of cereals" has highest genetic yield potential among cereals. It is considered as one of the most versatile emerging crops having wider adaptability under varied agro-climatic conditions and successful cultivation in diverse seasons and ecologies for various purposes. White corn on the other hand can be a substitute for rice and commonly referred to as the poor man's rice, in places where rice is the main staple food. It is cultivated on nearly $150 \mathrm{M}$ ha in about 160 countries having wider diversity of soil, climate, biodiversity and management practices that contributes 36\% (782 Mt) of the global grain production (Rao, 2013). Corn is the only grain which is totally dependent on human intervention for survival and that exists in thousands of different varieties (Labios, 2010). Although seen as food for the less privileged, corn has high nutritional value. It is 
rich in protein, fat, fiber and other essential vitamins and minerals including folate, iron, niacin, phosphorus, magnesium, copper and zinc. Corn also contains two essential amino acids, lysine and tryptophan, which provide numerous health benefits (Salazar, 2016).On the other hand, the plant spacing and NPK levels of corn production have great impact on climate change in agriculture. It adds significantly to the development and challenges of ensuring food security and reducing poverty. Increasing the population density of plant is an agronomical practice that has been studied. This crop technique has evolved and will continue to evolve over the years and it is agronomic management factor that has changed. Climate change urgently needs to be assessed at the level of the household, so that poor and vulnerable people dependent on agriculture can be appropriately targeted in research and development activities whose object is poverty alleviation. This study was established to support the production of white corn and to expand its promotion at a national level including the establishment of a more stable supply of white corn for the preferences of the different regions and the adaptation and dissemination of newly developed improved white corn varieties as alternative source of staple food.

Practicing a reduced tillage system typically had problems related to the forming of natural compaction, which is common when proper rotation is not followed. The situation could even worsen under smallholder farming activities where recommended plant density depends on the quantity of seed obtained due to cost. Considering the high demand of white corn and the low production to variably narrow and wide spacing, intensify the high density of corn production and plant population is thus, influenced by factors such as yield level, the amount of solar radiation, light intensity and the weather conditions can affect the plant spacing and nutrient management (NPK levels), however, within - row plant spacing uniformity does impact the grain yield, which is relatively small, averaging about $1-2 \%$ (Doerge et al., 2002). Among agronomic practices and proper fertilizer management, planting technique is of considerable importance as proper adjustment of plants in the field not only ensures optimum plant population but also enables the plants to utilize the land and other input resources more efficiently and resolutely towards growth and development (Imran et al., 2015).

Generally, this study was conducted to evaluate the growth, yield performance and quality of high protein corn as influenced by plant spacing and nutrient management (NPK levels).Specifically, it aimed to: 1. Determine the growth and yield response of high protein corn under different NPK levels and plant spacing; 2 determine the interaction effect of plant spacing and NPK levels on the growth and yield of high protein corn; and 3. Identify the plant population density of high protein corn that will give the highest yield.

\section{MATERIALS AND METHODS}

The experiment was laid out following the Split Plot in Randomized Complete Block Design (RCBD). The area was equally divided into 3 blocks. Each block was subdivided into 3 plots that represent the main treatment (plant spacing). The resulting plots were further sub-divided into 6 sub-plots to represent the sub - treatment (nutrient management). Each plot had an area of 20 square meters, 4 meters wide and 5 meters long ( $4 \mathrm{~m} \times 5 \mathrm{~m}$ ), consists of 5 to 6 rows. A 1.5 meter distance between blocks and 1 meter between plots were provided and maintained to ensure full confinement of the applied fertilizers and for the wide provision of the root system and to avoid fertilizer absorption and contamination of adjacent plants. The treatments were the following : Main Treatment - Plant Spacing: P1 - $70 \mathrm{~cm}$ x $20 \mathrm{~cm} ; \mathrm{P} 2-60 \mathrm{~cm}$ x $25 \mathrm{~cm}$; P3 $-60 \mathrm{~cm}$ x $20 \mathrm{~cm}$. Sub-Treatment - NPK Levels: F1 - $100-40$ - $20 \mathrm{~kg}$ ha-1; F2 - $130-40$ - $20 \mathrm{~kg}$ ha-1; F3 - $160-40-$ $20 \mathrm{~kg}$ ha-1; F4 - 100 - 40 - $60 \mathrm{~kg}$ ha-1; F5 - $130-40-60 \mathrm{~kg}$ ha-1; F6 - 160 - $40-60 \mathrm{~kg}$ ha-1. A field with an area of 2,000 square meters with a net area of 1,739 square meters, fairly leveled, well drained and suitable for corn growing was 
selected for this study. With the use of conventional tillage, the land was plowed twice with a one-week interval to allow the weeds to germinate. The field was properly harrowed until the desired tilt was attained.

\section{Experimental Observation Recorded}

To assess the effect of various treatments, different plant and growth parameters were studied: plant stand at harvest (\%), plant height at harvest $(\mathrm{cm})$, days to tasselling $(50 \%$ tasselling), ear height $(\mathrm{cm})$, ear length $(\mathrm{cm})$, ear diameter $(\mathrm{cm})$, ear harvest per plot (\%), kernel row per ear, number of kernels per ear, weight of 1000 per kernels (g), shelling recovery (\%) and computed kernel yield (ton $\mathrm{ha}^{-1}$ ).

\section{Statistical Analysis of Data}

Data collected were organized, tabulated and analyzed using Analysis of Variance (ANOVA) for split plot in Randomized Complete Block Design (RCBD). The IRRI STAR (version 2.0.1) was used to run the ANOVA. Means were compared using Tukey's Honest Significant Difference (HSD) Test at 0.05 level of confidence.

\section{RESULTS AND DISCUSSION}

The results obtained from the field experiments conducted to study the growth and yield of high protein corn as influenced by plant spacing and NPK levels are briefly summarized hereunder. The main treatments and sub-treatments and their effects were investigated on the important growth and yield parameters of high protein corn plant.

Results showed that NPK levels at the rate of 160-40-60 $\mathrm{kg} \mathrm{NP}_{2} \mathrm{O}_{5} \mathrm{~K}_{2} \mathrm{O}$ ha ${ }^{-1}(\mathrm{~F} 6)$ significantly gave the highest plant survival or plant stand at harvest with a mean of $98.99 \%$ within the harvested plot, while the lowest plant survival was recorded in NPK levels at the rate of $160-40-20 \mathrm{~kg} \mathrm{NP}_{2} \mathrm{O}_{5} \mathrm{~K}_{2} \mathrm{O}$ ha ${ }^{-1}(\mathrm{~F} 1)$ with a mean of $97.13 \%$. Results of the study revealed that there was a significant difference on plant survival on NPK levels due to the condition of stem lodging increases and intense of interplant competition for incident photosynthetic photon flux density, soil nutrients and soil water Abuzar et al. (2011).

The interaction of plant height was significantly affected $(p \leq 0.01)$ by plant spacing and NPK levels. Tallest plant with $263.98 \mathrm{~cm}$ was registered by plants planted at a distance of $60 \mathrm{~cm} \times 25 \mathrm{~cm}$ at the rate of $160-40-60 \mathrm{~kg} \mathrm{NP}_{2} \mathrm{O}_{5} \mathrm{~K}_{2} \mathrm{O}$ ha ${ }^{-1}$. The high amount of applied fertilizer (160-40-60 $\mathrm{kg} \mathrm{NP}_{2} \mathrm{O}_{5} \mathrm{~K}_{2} \mathrm{O}$ ha ${ }^{-1}$ compared to 100-40-20 $\mathrm{kg} \mathrm{NP}_{2} \mathrm{O}_{5} \mathrm{~K}_{2} \mathrm{O}$ ha ${ }^{-1}$ and 130-40$20 \mathrm{~kg} \mathrm{NP}_{2} \mathrm{O}_{5} \mathrm{~K}_{2} \mathrm{O}$ ha ${ }^{-1}$ ) improved the height of corn. The increase in plant height and the increase in the rate of nitrogen application could be attributed to positive effect of $\mathrm{N}$ on vigorous vegetative growth due to more availability of $\mathrm{N}$ throughout the growing period that corroborates with the study of Kumar et al. (2002) who all revealed that plant height increase indicated that the nitrogen fertilizer promoted plant growth, increased the number of internodes and length of the internodes which resulted in progressive increase in plant height Zamir et al.(2011).

No significant interaction was noted between plant spacing and NPK levels. Fertilizer 6 at the rate of 160-40-60 $\mathrm{kg} \mathrm{NP}_{2} \mathrm{O}_{5} \mathrm{~K}_{2} \mathrm{O}$ ha $^{-1}$ registered the longest days in terms of tasseling with a mean of 61.21 , while Fertilizer 1 at the rate of 100-40-20 kg NP $\mathrm{O}_{5} \mathrm{~K}_{2} \mathrm{O}$ ha ${ }^{-1}$ registered the shortest days in terms of tasseling with a mean of 59.49. Mean values of the data showed that increasing the fertilizer levels consistently increased the number of days to tasseling. The different treatment combination of fertilizer application enhanced the time to reach 50\% tasseling. The nutrients might have reduced the rate of phenological development that ultimately delayed maturity period and that the application of mineral $\mathrm{N}$ sustained leaf photosynthesis during active crop growth stage and extended the duration of vegetative growth (days to 
tasseling). Plant spacing, NPK levels and its interaction significantly affected $(p \leq 0.01)$ ear height of high protein corn (Parmar, 2015).The trend indicated consistent increment in ear height with increment of different fertilizer rates and plant spacing. An increase in ear height at higher NPK levels could be attributed to lower competition for nutrient that allowed the plants to accumulate more biomass with higher capacity to convert more photosynthesis resulting in taller ear height. The observed increased in ear length as a result of increasing population density showed that the planting density above and below the critical level brings a negative effect on the formation of ear length. This can be attributed to the effects of inter plants competition for light water, nutrient and other potential environmental factors (Jiban, 2013). The result showed that higher plant density due to the comparatively less competition for resources of the plants resulted to a significant size of ear diameter. The greater plant population per unit area at this condition means that the plants competed for nutrients, sunlight, water and space for good growth and development and effective suppression of fertilizer levels and plant spacing of the corn (Ayman and Samier, 2015)

Table 1: Interaction Effect of Plant Spacing and NPK Levels on Plant Stand at Harvest (\%), Plant Height at Harvest (cm), Days to tasselling (50\% tasseling), Ear Height $(\mathrm{cm})$, Ear Length $(\mathrm{cm})$ and Ear Diameter $(\mathrm{cm})$

\begin{tabular}{|c|c|c|c|c|c|c|}
\hline Treatments & $\begin{array}{c}\text { Plant Stand } \\
\text { at Harvest }\end{array}$ & $\begin{array}{l}\text { Plant Height at } \\
\text { Harvest }(\mathbf{c m})\end{array}$ & $\begin{array}{l}\text { Days to tasselling } \\
\text { (50\% tasseling) }\end{array}$ & $\begin{array}{l}\text { Ear Height } \\
(\mathrm{cm})\end{array}$ & $\begin{array}{c}\text { Ear } \\
\text { Length } \\
(\mathrm{cm}) \\
\end{array}$ & $\begin{array}{c}\text { Ear } \\
\text { Diameter } \\
(\mathbf{c m})\end{array}$ \\
\hline \multicolumn{7}{|l|}{ Plant Spacing } \\
\hline $\begin{array}{c}\mathrm{P} 1(70 \mathrm{~cm} x \\
20 \mathrm{~cm})\end{array}$ & 98.44 & 239.98 & 60.34 & $87.53^{\mathrm{c}}$ & $17.82^{\mathrm{b}}$ & $4.19^{c}$ \\
\hline $\begin{array}{c}\mathrm{P} 2(60 \mathrm{~cm} \mathrm{x} \\
25 \mathrm{~cm})\end{array}$ & 97.69 & 251.29 & 60.12 & $87.71^{b}$ & $19.58^{\mathrm{a}}$ & $4.39^{\mathrm{a}}$ \\
\hline $\begin{array}{c}\mathrm{P} 3(60 \mathrm{~cm} \times \\
20 \mathrm{~cm})\end{array}$ & 97.74 & 244.89 & 60.51 & $88.19^{\mathrm{a}}$ & $19.54^{\mathrm{ab}}$ & $4.23^{\mathrm{b}}$ \\
\hline \multicolumn{7}{|l|}{ NPK levels } \\
\hline $\begin{array}{l}\text { F1 (100-40- } \\
\left.20 \mathrm{~kg} \mathrm{ha}^{-1}\right)\end{array}$ & $98.52^{\mathrm{ab}}$ & $251.22^{\mathrm{a}}$ & $59.49^{\mathrm{b}}$ & $86.53^{\mathrm{d}}$ & $18.84^{b c}$ & $4.20^{\mathrm{c}}$ \\
\hline $\begin{array}{c}\text { F2 (130-40- } \\
\left.20 \mathrm{~kg} \mathrm{ha}^{-1}\right)\end{array}$ & $98.14^{\mathrm{ab}}$ & $239.71^{c}$ & $60.31^{\mathrm{ab}}$ & $88.36^{\mathrm{ab}}$ & $18.89^{\mathrm{b}}$ & $4.28^{\mathrm{b}}$ \\
\hline $\begin{array}{c}\text { F3 (160-40- } \\
\left.20 \mathrm{~kg} \mathrm{ha}^{-1}\right)\end{array}$ & $97.13^{\mathrm{b}}$ & $244.90^{\mathrm{b}}$ & $60.52^{\mathrm{ab}}$ & $87.36^{\mathrm{bc}}$ & $18.76^{\mathrm{c}}$ & $4.20^{\mathrm{c}}$ \\
\hline $\begin{array}{l}\text { F4 (100-40- } \\
\left.60 \mathrm{~kg} \mathrm{ha}^{-1}\right)\end{array}$ & $97.15^{\mathrm{b}}$ & $244.90^{\mathrm{b}}$ & $59.94^{\mathrm{ab}}$ & $87.20^{\mathrm{c}}$ & $18.61^{\mathrm{d}}$ & $4.32^{\mathrm{ab}}$ \\
\hline $\begin{array}{c}\text { F5 (130-40- } \\
\left.60 \mathrm{~kg} \mathrm{ha}^{-1}\right)\end{array}$ & $97.81^{\mathrm{ab}}$ & $244.97^{\mathrm{b}}$ & $60.47^{\mathrm{ab}}$ & $89.37^{\mathrm{a}}$ & $19.54^{\mathrm{a}}$ & $4.25^{\mathrm{bc}}$ \\
\hline $\begin{array}{c}\text { F6 (160-40- } \\
\left.\text { 60 } \mathrm{kg} \mathrm{ha}^{-1}\right)\end{array}$ & $98.99^{\mathrm{a}}$ & $246.63^{\mathrm{ab}}$ & $61.21^{\mathrm{a}}$ & $87.54^{\mathrm{b}}$ & $19.14^{\mathrm{ab}}$ & $4.37^{\mathrm{a}}$ \\
\hline
\end{tabular}
$\mathrm{p} \leq 0.05$

Presented in table 2 is the NPK levels significantly $(p \leq 0.05)$ affected the ear harvest per plot, but no significant interaction was observed between plant spacing and NPK levels. The increase in ear harvest per plot with higher nitrogen rate due to the increased uptake of all the nutrients that helps the translocation of photosynthetic materials and the quantity of fertilizer combinations applied showed the positive effect of number of ear produced. However, the nutrient management affects the significant reduction in ear harvest per plot due to the supply of nitrogen, photosynthates and water to the growing ear (Khah et al., 2012).

On the other hand, plant spacing, NPK levels and its interaction significantly $(p \leq 0.01)$ affected the kernel row per ear of high protein corn. The increase of kernel per row affected by plant spacing and NPK levels could be attributed to the plant competition at higher plant densities leading to availability of nutrients that affect the increase of kernel formation. 
Increased in number of kernels per ear was due to higher NPK levels with average competition for nutrients and other growth factors credited to the plant population density. It allowed the accumulation of more biomass, caused by the assimilation of absorbed nutrients from the soil that affects the kernel formation (Nik et al., 2012).

The determinative effect of moisture availability in the forthcoming grain filling that affects the weight of 1000 kernels, it is also providing relatively favorable moisture conditions for the major part of the growing season was due to partly less competition for water, light, plant spacing (wider) and fertilizer levels which assimilate the kernels during the process of kernel filling (Salazar et al., 2017).

The highest shelling recovery applied with different NPK levels was recorded to Fertilizer 4 at the rate of 100-40$60 \mathrm{~kg} \mathrm{NP}_{2} \mathrm{O}_{5} \mathrm{~K}_{2} \mathrm{O}$ ha ${ }^{-1}$ with a mean of $82.10 \%$ while the lowest shelling recovery applied with different NPK levels was recorded to Fertilizer 6 at the rate of $160-40-60 \mathrm{~kg} \mathrm{NP}_{2} \mathrm{O}_{5} \mathrm{~K}_{2} \mathrm{O}$ ha ${ }^{-1}$ with a mean of $79.49 \%$. In terms of plant spacing, plants planted at a distance of $60 \mathrm{~cm} \times 25 \mathrm{~cm}$ obtained the highest shelling recovery with a mean of $82.01 \%$, results of the study implied that the kernel formation was highly and strongly affected by different treatment combinations especially the NPK levels and since increase of percentage of shelling recovery had a greater improvement corresponding to the economic yield and there was more availability of growth factors and better penetration of light at wider row spacing (Tahmashbi and Mohasel, 2010).

Computed kernel yield was significantly influenced by different fertilizer levels due to high plant density that ascribed to a greater number of plants and number of ears produced per unit area. Increased in kernel yield at optimum planting densities attributed the availability of more nutrients which led to more growth and development of kernels (Khan et al., 2012).

Table 2: Interaction Effect of Plant Spacing and NPK Llevels on Ear Harvest Per Plot (\%), Kernel Row Per Ear, Number of Kernels Per Ear, Weight of 1000 Kernels (kg), Shelling Recovery (\%) and Computed Kernel Yield (ton ha-1)

\begin{tabular}{|c|c|c|c|c|c|c|}
\hline Treatments & $\begin{array}{l}\text { Ear Harvest } \\
\text { per Plot }(\%)\end{array}$ & $\begin{array}{c}\text { Kernel Row } \\
\text { per Ear }\end{array}$ & $\begin{array}{l}\text { Number of } \\
\text { Kernels per } \\
\text { Ear }\end{array}$ & $\begin{array}{l}\text { Weight of } \\
1000 \text { kernels } \\
(\mathrm{kg})\end{array}$ & $\begin{array}{c}\text { Shelling } \\
\text { Recovery (SR) } \\
(\%)\end{array}$ & $\begin{array}{c}\text { Computed } \\
\text { Kernel Yield } \\
\left(\text { ton } \mathrm{ha}^{-1}\right)\end{array}$ \\
\hline \multicolumn{7}{|l|}{$\begin{array}{c}\text { Plant } \\
\text { Spacing }\end{array}$} \\
\hline $\begin{array}{l}\mathrm{P} 1(70 \mathrm{~cm} \mathrm{x} \\
20 \mathrm{~cm})\end{array}$ & 99.32 & $16.26^{\mathrm{b}}$ & 740.26 & 0.281 & $79.79^{\mathrm{b}}$ & 3.612 \\
\hline $\begin{array}{c}\mathrm{P} 2(60 \mathrm{~cm} \mathrm{x} \\
25 \mathrm{~cm})\end{array}$ & 100.09 & $17.29^{\mathrm{a}}$ & 893.16 & 0.273 & $82.01^{\mathrm{a}}$ & 3.835 \\
\hline $\begin{array}{l}\text { P3 }(60 \mathrm{~cm} \mathrm{x} \\
20 \mathrm{~cm})\end{array}$ & 99.05 & $15.85^{\mathrm{c}}$ & 950.85 & 0.284 & $80.35^{\mathrm{b}}$ & 3.675 \\
\hline \multicolumn{7}{|l|}{ NPK levels } \\
\hline $\begin{array}{l}\text { F1 (100-40- } \\
\left.20 \mathrm{~kg} \mathrm{ha}^{-1}\right)\end{array}$ & $98.33^{b}$ & $16.34^{\mathrm{ab}}$ & $943.47^{\mathrm{a}}$ & $0.275^{\mathrm{bc}}$ & $79.78^{\mathrm{ab}}$ & $3.77^{\mathrm{ab}}$ \\
\hline $\begin{array}{c}\text { F2 }(130-40- \\
\left.20 \mathrm{~kg} \mathrm{ha}^{-1}\right)\end{array}$ & $99.55^{\mathrm{ab}}$ & $16.50^{\mathrm{ab}}$ & $822.67^{\mathrm{c}}$ & $0.277^{\mathrm{b}}$ & $81.11^{\mathrm{ab}}$ & $3.42^{\mathrm{b}}$ \\
\hline $\begin{array}{c}\text { F3 }(160-40- \\
\left.20 \mathrm{~kg} \mathrm{ha}^{-1}\right)\end{array}$ & $99.15^{\mathrm{b}}$ & $16.26^{\mathrm{b}}$ & $820.86^{\mathrm{d}}$ & $0.275^{\mathrm{bc}}$ & $80.63^{\mathrm{ab}}$ & $3.66^{\mathrm{ab}}$ \\
\hline $\begin{array}{l}\text { F4 (100-40- } \\
\left.60 \mathrm{~kg} \mathrm{ha}^{-1}\right)\end{array}$ & $99.71^{\mathrm{ab}}$ & $17.04^{\mathrm{a}}$ & $843.64^{\mathrm{b}}$ & $0.287^{\mathrm{ab}}$ & $82.10^{\mathrm{a}}$ & $3.34^{\mathrm{c}}$ \\
\hline $\begin{array}{c}\text { F5 }(130-40- \\
\left.60 \mathrm{~kg} \mathrm{ha}^{-1}\right)\end{array}$ & $98.89^{b}$ & $16.26^{\mathrm{b}}$ & $836.48^{\mathrm{bc}}$ & $0.290^{\mathrm{a}}$ & $81.20^{\mathrm{ab}}$ & $3.92^{\mathrm{a}}$ \\
\hline $\begin{array}{l}\text { F6 (160-40- } \\
\left.60 \mathrm{~kg} \mathrm{ha}^{-1}\right)\end{array}$ & $101.29^{\mathrm{a}}$ & $16.40^{\mathrm{ab}}$ & $901.41^{\mathrm{ab}}$ & $0.272^{\mathrm{c}}$ & $79.49^{\mathrm{b}}$ & $4.12^{\mathrm{a}}$ \\
\hline
\end{tabular}

$\mathrm{p} \leq 0.05$ 


\section{CONCLUSIONS}

Based on the results of the study plant spacing of $60 \mathrm{~cm} \times 25 \mathrm{~cm}$ and $60 \mathrm{~cm} \times 20 \mathrm{~cm}$ and NPK levels at the rate of $130-40-60$ $\mathrm{kg} \mathrm{NP}_{2} \mathrm{O}_{5} \mathrm{~K}_{2} \mathrm{O} \mathrm{ha}^{-1}$ and $160-40-60 \mathrm{~kg} \mathrm{NP}_{2} \mathrm{O}_{5} \mathrm{~K}_{2} \mathrm{O}$ ha ${ }^{-1}$ increased growth parameters (plant stand at harvest, plant height, days to tasseling, ear height) and yield and yield components (ear harvest per plant, kernel row per ear, number of kernels per row, ear length, weight of 1000 kernels, computed kernel yield and shelling recovery) gave significant effects on the high protein corn. Application of fertilizer combinations during the crop production was effective which contributed to the increased yield. This indicated that supplemental fertilizer combinations (chemical fertilizers) also improved and nurtured the plant growth and development, thus higher yield was attained.

\section{REFERENCES}

1. Abuzar, M.R., G.U. Sadozai, M.S. Baloch, A.A. Baloch and I.H. Shah (2001). Effect of plant population densities on yield of maize. J Ani and Plant Sci 21: pp. 692-695.

2. Ayman, H. A. and K.A. Samier (2015). Maize productivity as affected by plant density and nitrogen fertilizer. International Journal of Current Microbiology Applied Science 4(6): 870-877.

3. Damaso, A.V. (2013). Growth and Yield Performance of Different Watermelon (Citrullus lanatus Thund.) Varieties as Affected by Organic and Inorganic Fertilizers. Undergraduate Thesis of Pangasinan State University-Sta. Maria Campus, Sta. Maria, Pangasinan, Philippines.

4. Doerge, T. E. (2002). New Research Confirms Benefits of Improved Plant Spacing in Corn. Crop Insights (Pioneer Hi-Bred International, $38-42$.

5. Imran, S., M. Arif, A. Khan, W. Shah, L. Abdul, and M. Ali Khan (2015). Effect of nitrogen levels and plant population on yield and yield components of maize. Advanced Crop Science Technology3: 170.

6. Imran, S., M. Arif, A. Khan, M. Ali Khan, W. Shah and A. Latif (2015). Effect of Nitrogen Levels and Plant Population on Yield and Yield Components of Maize. The University of Agriculture, Peshawar, Khyber Pakhtunkhwa, Pakistan. Agriculture Research Institute (ARI) Tarnab Peshawar, Pakistan, Advances in Crop Science and Technology.

7. Jiban, S. (2013). Effect of nitrogen and plant population on flowering and grain yield of winter maize. Sky Journal of Agricultural Research 2(5):64 - 68.

8. Khah M.N., R.M. Kheibari, S.K. Khorasani and G. Taheri (2012). Effects of plant density and variety on some of morphological traits, yield and yield components of baby corn (Zea mays L). Int Res J of Applied and Basic Sci 3: 2009-2014.

9. Khalil, S.K., M.S. Afridi and M. Iqbal (1988). Plant height, weeds weight and hay yield of maize and mungbean in mono and associated culture as affected by NPK application. Sarhad Journal of Agriculture 4: 377-385.

10. Labios, R. E. (2010). Maize in Philippines: Production System, Constraints, and Research Priorities. Agricultural Sciences Journal 67-72.

11. Nik, M.M., Mahdi, B., T. Abolfazl and A. Ahmad (2012). Effect of plant density on yield and yield components of corn hybrids (Zea mays L.). Scientific Research and Essays 6(22):4821-4825.

12. Parmar, D.K. (2015). Nitrogen requirement of single hybrid maize (Zea mays L.) - wheat (Triticum aestivum) system under rainfed conditions. Indian J. agric. Sci., 71 (4): 252-254.

13. Rao, V. P. (2013). International Journal of Plant, Animal and Environmental Sciences. Agronomic Responses of Maize to Plant Population and Nitrogen Availability -A Review, 107-116. 
14. Salazar, A., A. Bautista and P. Manguiat (2017). Agronomic Characteristics of Quality Protein Maize - IPB Var 6. University of the Philippines Los Baños-Institute of Plant Breeding, Crop Science Cluster.

15. Salazar, A. (2016). Importance of High Protein Corn as Staple Food. University of the Philippines Los Baños-Institute of Plant Breeding Journal, 1-10.

16. Tahmasbi, A. and M.H. Rashed Mohasel, (2010). The effect of density and planting pattern on yield and yield components of two corn hybrids (KSC700 and KSC704) in Kurdistan. Journal of Iran's Agronomical Researches 7(1): 105-113.

17. Zamir M. S. I., A. H. Ahmad, H. M. R. Javeed and T. Latif (2011). Growth and yield behavior of two maize hybrids (Zea mays L.) towards different plant spacing. Cercetri Agronomice in Moldova. 14(2): 33-40.

18. Zamir, M.S.I., G. Yasin, H.M.R. Javeed, A.U.H. Ahmad, A. Tanveer and M. Yaseen (2013). Effect of different sowing techniques and mulches on the growth and yield behavior of spring planted maize (Zea mays L.). Cercetri Agronomice in Moldova 1(153): 77-82.

19. Saif-Ur-Rehman, Saif Abbasi, and Qamar Abbas Jafri. "Role of Women in Crop Production in District Pakpattan, Pakistan." International Journal of Agricultural Science and Research (IJASR) 3.3 (2013):161-170

20. Kuttimani, E. Somasundaram, and K. Velayudham. "Eco Friendly Nutrient Management Practices for Yield and Soil Organic Carbon, in Banana." International Journal of Applied and Natural Sciences (IJANS) 6.6 (2017):55 - 60

21. Mahla, Sunil Kumar, and S. S. Wanjari. "Response of Wheat to Irrigation and Hydrogel with Nutrient Management." International Journal of Agricultural Science and Research (IJASR) 7.2 (2017): 267-272.

22. Shashank, D., et al. "Comparative Analysis of Knowledge Level of Paddy Farmers on Nutrient Management." International Journal of Agricultural Science and Research (IJASR) 6.6 (2016):235-238

23. Basak, Debojit., and Jagadish Chandra Jana. "Performances on growth and rhizome sizes of turmeric (Curcuma longa L.) Varieties, grown under Conventional and organic nutrient management practices under terai region of west Bengal." International Journal of Agricultural Science and Research (IJASR), 6.2 (2016): 257-262.

24. Gangadharan, S., and C R Chinnamuthu. "Influence of Intercropping and Nutrient Management Practices on Insect Pest Population of Traditional Red Rice." International Journal of Agricultural Science and Research (IJASR) 6.2 (2016):251-256 

